\title{
RESENHAS|REVIEWS
}

SIMÕES, Fabiana Coelho. Instrumentos de controle social da corrupção: análise da legislação e das propostas de medidas anticorrupção. Rio de Janeiro: Lumen Juris, 2019. 156 p.

\section{COMPREENDER OS MECANISMOS DE COMBATE À CORRUPÇÃo}

\section{Adriano da Silva Ribeiro ${ }^{1}$}

Como citar: RIBEIRO, Adriano da Silva. Compreender os mecanismos de combate à corrupção. Em: SIMÕES, Fabiana Coelho. Instrumentos de controle social da corrupção: análise da legislação e das propostas de medidas anticorrupção. Rio de Janeiro: Lumen Juris, 2019. 156 p. Scientia Iuris, Londrina, v. 25, n. 3, p. 192-194, nov. 2021. DOI: 10.5433/2178-8189.2021v25n 3p192. ISSN: 2178-8189.

A obra é de significativo valor para o Direito Público, Ciência Política, Gestão e Administração Pública, vez que apresenta estudo a respeito do fenômeno da corrupção no Brasil. O título do livro de Fabiana Coelho Simões é "Instrumentos de controle social da corrupção: análise da legislação e das propostas de medidas anticorrupção”, lançado em 2019, pela Lumen Juris, e estrutura-se em prefácio e cinco capítulos.

A proposta da Professora Fabiana Coelho Simões na dissertação de mestrado defendida no curso de Mestrado Acadêmico junto ao Programa de Pós-Graduação Stricto Sensu em Direito da Universidade FUMEC, sob a orientação da Professora Doutora Maria Tereza Fonseca Dias, é justamente compreender os mecanismos de combate à corrupção na legislação brasileira e investigar o papel do controle social da Administração Pública nessa seara.

Em curto prefácio, a Professora Doutora Maria Tereza Fonseca Dias apresenta a obra e evidencia que "o problema que foi levantado pelo trabalho é sofisticado, pois não se contenta com a mera descrição dos instrumentos jurídicos (atuais e potenciais) de combate à corrupção, mas intenta saber o papel que é dado ao controle social, tanto na legislação existente quanto nas propostas mais recentes de enfrentamento do problema".

Inicia a Professora Fabiana Coelho Simões seu trabalho com a análise dos meios de controle tradicionais e os desdobramentos de sua aplicação, enfatizando os resultados e falhas de sua adoção. Destaca que os controles interno e externo, bem assim o controle judicial, o controle legislativo e o controle social, existentes atualmente, mas, não inibem a "recorrência da prática de crimes contra a Administração Pública, o que compromete a eficiência do serviço público e o atendimento do interesse comum".

Segundo a autora, quanto à corrupção, houve transformação legislativa, resultado de

1 Doutor em Ciências Jurídicas e Sociais pela Universidad del Museo Social Argentino. E-mail: adrianoribeiro@ yahoo.com 
vinculação a compromissos internacionais assumidos. E, destaca a Professora, "a publicidade dada aos casos investigados na operação "Lava Jato" proporcionou maior debate sobre o tema da corrupção e a população se viu mais integrada e participativa, o que, de forma direta ou indireta, fomenta o controle social" (SIMÕES, 2019, p. 27).

No terceiro capítulo, a Professora Fabiana Simões investiga os mecanismos de controle social, a partir da legislação brasileira sobre o tema, justamente para compreender se as leis que versam sobre o combate à corrupção estão em consonância com o processo de democratização da Administração Pública contemporânea. Analisou a autora os princípios estruturantes do Direito Administrativo em face das leis de combate à corrupção, a compatibilidade ou distanciamento entre eles, com destaque para os mecanismos de controle social previsto na legislação.

A Professora Fabiana Simões apresenta ao leitor com riqueza de detalhes o fenômeno da corrupção no Brasil, conceito e historicidade, bem assim os contornos de sua prática, mediante apontamento das deficiências de seu controle e a tendência de transformação legislativa para o seu enfrentamento. Afirma a autora que: "[...] a prática de infrações contra a Administração Pública que culminam em atos de corrupção continua desafiando as instâncias democráticas de controle, que, no plano fático, encontram deficiências que devem ser identificadas, trabalhadas e superadas" (SIMÕES, 2019, p. 81).

Por conseguinte, no quarto capítulo, a autora se debruça sobre as novas medidas anticorrupção propostas e a sua potencialidade para transformar o paradigma de controle da corrupção no Brasil, evidenciando-se a reformulação ou reinterpretação dos mecanismos tradicionais e a formulação de proposta para a efetivação do controle social.

Nesse contexto, incontáveis são as contribuições que a Professora Fabiana Coelho Simões trouxe para a compreensão da efetivação do controle social da corrupção. Na obra, encontramos a seguinte interpretação da Advogada, Professora e consultora em Direito Administrativo e Regulatório, Maria Tereza Fonseca Dias: “as propostas de combate à corrupção ainda são tímidas quanto ao efetivo papel da sociedade nessa tarefa. O principal achado dessa obra, no esteio do que já se vem discutindo desde a redemocratização do País, é que a inibição das práticas de corrupção somente será efetiva quando instituídos mecanismos que aproxima o Estado da sociedade e quando houver a abertura do sistema administrativo para uma gestão cada vez mais democrática e transparente".

É o que defende a Professora Fabiana Simões: "os mecanismos de controle social têm apresentado mudanças, em que o cidadão e o Estado vêm tentando construir a eficácia dos mecanismos disponíveis, garantindo, principalmente, a transparências das ações administrativas por meio da publicidade [...]".

De fato, traz significativa contribuição para a pesquisa do tema anticorrupção no Brasil, principalmente no que tange à pesquisa das leis brasileiras e das novas propostas apresentadas nas casas legislativas. Trabalho dotado de alta técnica, profundidade e olhar crítico, que, para além de identificar problemas, apresenta soluções coerentes orientadas à construção de uma participação popular e efetivo controle social. 


\section{REFERÊNCIA}

SIMÕES, Fabiana Coelho. Instrumentos de controle social da corrupção: análise da legislação e das propostas de medidas anticorrupção. Rio de Janeiro: Lumen Juris, 2019. 156 p. ISBN 97885-519-199-8

Como citar: RIBEIRO, Adriano da Silva. Compreender os mecanismos de combate à corrupção. Em: SIMÕES, Fabiana Coelho. Instrumentos de controle social da corrupção: análise da legislação e das propostas de medidas anticorrupção. Rio de Janeiro: Lumen Juris, 2019. 156 p. Scientia Iuris, Londrina, v. 25, n. 3, p. 192-194, nov. 2021. DOI: 10.5433/2178-8189.2021v25n 3p192. ISSN: 2178-8189. 